\title{
An Experimental Study on the Water-Induced Strength Reduction in Zigong Argillaceous Siltstone with Different Degree of Weathering
}

\author{
Yu-chuan Yang, ${ }^{1}$ Jia-wen Zhou, ${ }^{1}$ Fu-gang Xu, ${ }^{2}$ and Hui-ge Xing ${ }^{3}$ \\ ${ }^{1}$ State Key Laboratory of Hydraulics and Mountain River Engineering, Sichuan University, Chengdu 610065, China \\ ${ }^{2}$ College of Water Resources and Hydropower, Sichuan University, Chengdu 610065, China \\ ${ }^{3}$ College of Architecture and Environment, Sichuan University, Chengdu 610065, China \\ Correspondence should be addressed to Hui-ge Xing; hgxing@scu.edu.cn
}

Received 13 April 2016; Accepted 14 August 2016

Academic Editor: Giorgio Pia

Copyright ( 2016 Yu-chuan Yang et al. This is an open access article distributed under the Creative Commons Attribution License, which permits unrestricted use, distribution, and reproduction in any medium, provided the original work is properly cited.

\begin{abstract}
The water-softening property of soft rocks is a key problem in geotechnical engineering. A typical red-bed soft rock (the Zigong argillaceous siltstones) with different weathering degree is selected as an example to study the water-softening property and the influence of degree of weathering. A series of mechanical and microstructure tests are carried out to analyze the weathering characteristics and mechanism of the Zigong argillaceous siltstones. The results of mechanical experiments reveal that the water content and the weathering degree of rock specimens both have a weakening effect on the compressive and shear strengths. According to the results of present microstructure tests, the mechanical properties of the Zigong argillaceous siltstones are closely correlated with their physical properties, including internal microstructure and material composition for highly weathered rocks or moderately weathered rocks (in both natural and saturation conditions). Finally, experimental results indicate that the changes of microstructure and internal materials are two main factors that influence rock strength parameters after contacting with water and that these properties reflect the rock weathering degree. In a word, when red-bed soft rocks are encountered in geotechnical engineering, special attention should be paid to presence of water.
\end{abstract}

\section{Introduction}

There are many types of red-bed soft rocks such as red siltstone and red mudstone, which are widely distributed at the Sichuan basin, the Shanganning basin, the Yunnan plateau, and other places in China [1]. The Sichuan Province belongs to typical inland basin known as "Red Basin," and the elevations of the inland basin are about $200 \mathrm{~m}$ to $750 \mathrm{~m}$ with hilly regions as the main geomorphic units. It is generally believed that the iron element in rocks is oxidized to trivalent iron due to the strong oxidation, which is the reason of forming the red appearance $[2,3]$. Among these areas, the basis formation condition of red-bed rocks is the proper geomorphological environment with dry and hot paleoclimate, weathering conditions, and rich sediments source from mountains. The different forming conditions, tectonic activity, and climate lead to the differences of the red-bed rocks in colors, microstructure, mineral composition, weathering degree, and others [3]. The widely distributed red-bed rocks have special mechanical properties (especially for the soft rocks) and are often encountered during the construction process of civil engineering. However, the red-bed soft rocks are mostly exposed below the ground surface and are sensitive to the water; therefore the water-softening and weathering are two main problems for the red-bed soft rocks.

In geotechnical engineering, the water-softening effect on mechanical properties of the soft rock is one of the important theoretical and practical problems. Among Southwest China, most red beds belong to soft rocks' category because its physical and mechanical properties are very poor relatively $[1,2,4]$. Such rocks have lower strength (saturated uniaxial compressive strength of rock mass less than $30 \mathrm{MPa}$ ), larger porosity, 


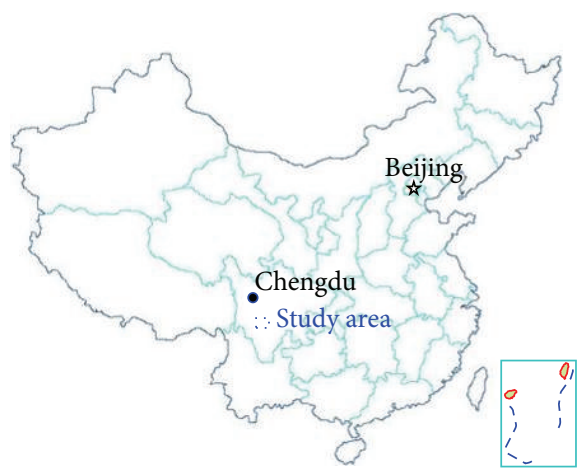

(a)

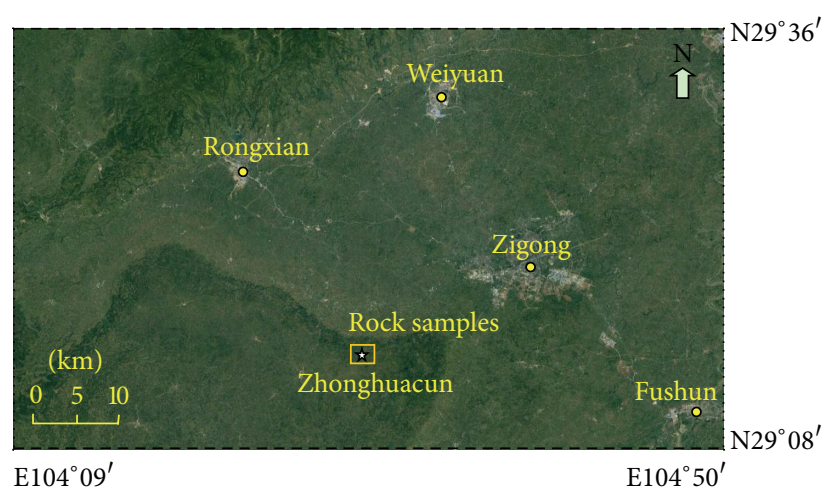

(b)

FIGURE 1: Location of the test samples for red-bed soft rock: (a) site location of the study area and (b) the Zigong argillaceous siltstone samples are collected from the Zhonghuacun reservoir area.

and poorer cementation degree than hard rocks [4]. The lithologies of red beds are mainly sandstone, siltstone, silty mudstone, argillaceous siltstone, shale, or claystone. When they encounter water, the red beds commonly develop many engineering problems such as erosion, seepage, and softening $[2,3,5]$. With the development of engineering construction in the red-bed areas, more researchers begin to pay more attention to the physical and mechanical properties of soft rocks [2, 5-10]. For example, Arnould (2006) analyzed the reasons of mudstone easily disintegrating from the perspective of mudstone internal mineral composition and microstructure [6]. Chen et al. (2014) studied a shallow progressive landslide developed in loose deposits of red beds by analyzing mechanical properties of the main slip zone and its microstructure using polarising microscopy (PM) and scanning electron microscope (SEM) techniques [2]. In order to study the features of rock-water interaction of natural soft rock, Guo et al. (2015) analyzed the hydrophilic characteristics at high stress state combining X-ray diffraction and mercury injection tests [7].

Previous studies have revealed that water is the most notable factor lowering rock strength, but few works focused on the relationship of the water-softening properties with the microscopic softening mechanism, which can be analyzed based on its microstructure change law for rock mass with different degree of weathering. This paper treated the Zigong argillaceous siltstone as a special example of red-bed soft rock, which is a common soft rock encountered in geotechnical engineering. A series of mechanical and microstructure tests were carried out to study the water-softening properties of the Zigong argillaceous siltstone under different degree of weathering, some useful conclusions are presented in this paper.

\section{Material and Methods}

2.1. Material. The argillaceous siltstone is selected from the Zhonghuacun reservoir (E104 $32^{\prime} 56^{\prime \prime}$, N29 $15^{\prime} 8^{\prime \prime}$ ), locating at Zhonghuacun, Gongjing District, Zigong City, Sichuan Province, China (as shown in Figure 1). The Zhonghuacun dam site lies about $25 \mathrm{~km}$ from the Zigong City. The reservoir is a small water project offering emergency backup water source of Gongjing District, Zigong City. The irrigation area of the reservoir is $6.986 \times 10^{6} \mathrm{~m}^{2}$.

By some test pits and vertical boreholes, horizontal geological tunnels for geological survey works, the Zigong argillaceous siltstone was collected in different drilling depths. According to drilling results, the drilling depths of the highly and moderately weathered argillaceous siltstones are about $5-13 \mathrm{~m}$ and $15-25 \mathrm{~m}$ as shown in Figures 2(b) and 2(c), respectively. The digenesis of natural argillaceous siltstones is poor, so it is easy to cause weathering fissures for depositional interface. When water enters its internal pores, the rock can produce inflation and softening phenomenon easily.

Furthermore, the physical and mechanical properties of rock mass often depend on its material compositions. Test results indicate that the elemental composition of the highly and moderately weathered Zigong argillaceous siltstones contain a lot of soluble salts, and there are many soluble cements with chemically active elements such as $\mathrm{K}, \mathrm{Na}$, and $\mathrm{Fe}$ (as shown in Figure 3). The argillaceous siltstones mainly consist of the ten elements such as $\mathrm{O}, \mathrm{Si}, \mathrm{C}, \mathrm{Ca}, \mathrm{Al}, \mathrm{Fe}, \mathrm{K}, \mathrm{Mg}$, $\mathrm{Na}$, and $\mathrm{Ti}$. For the moderately weathered rock, the content of four elements $\mathrm{O}, \mathrm{Si}, \mathrm{C}$, and $\mathrm{Ca}$ reaches $89.22 \%$ and the minimum content is $3.25 \%$ for the four elements $\mathrm{K}, \mathrm{Mg}, \mathrm{Na}$, and $\mathrm{Ti}$ (Figure 3(a)). For the highly weathered rock, the content of three elements $\mathrm{O}, \mathrm{Al}$, and Fe increases to $64.52 \%$ from $55.26 \%$, while the content of two elements $\mathrm{C}$ and Ca decreased significantly to $7.43 \%$ from $16.92 \%$ because of the destruction of some carbon skeletons and decomposition of calcium carbonate (Figure 3(b)). Elemental compositions results show that the elemental composition changes with the degree of weathering significantly.

When the argillaceous siltstones encounter water, these soluble cements are easy to react with water that will lead to lost connectivity between rock particles. After some materials dissolve in the water, rock pore solution is easy to cause the interaction with its internal clay minerals again. That means the water can cause great effect on the physical and mechanical properties of the Zigong argillaceous siltstone. Below, we 


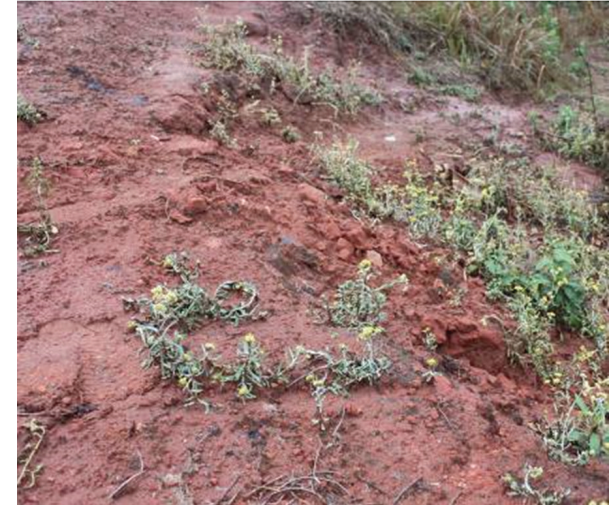

(a)

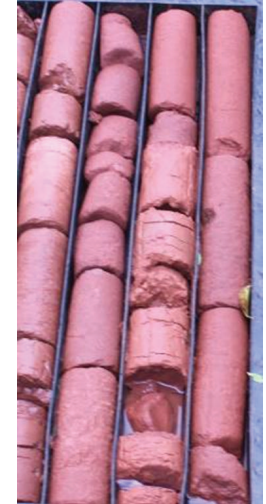

(b)

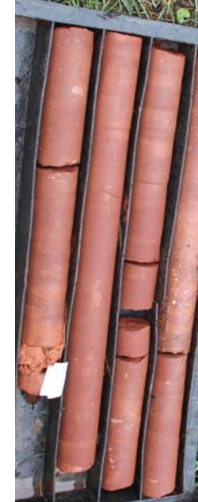

(c)

FIGURE 2: Site photos of the Zigong argillaceous siltstone: (a) completely weathered at the shallow surface (a type of silty clay); (b) borehole core samples of the highly weathered argillaceous siltstone and (c) borehole core samples of the moderately weathered argillaceous siltstone.

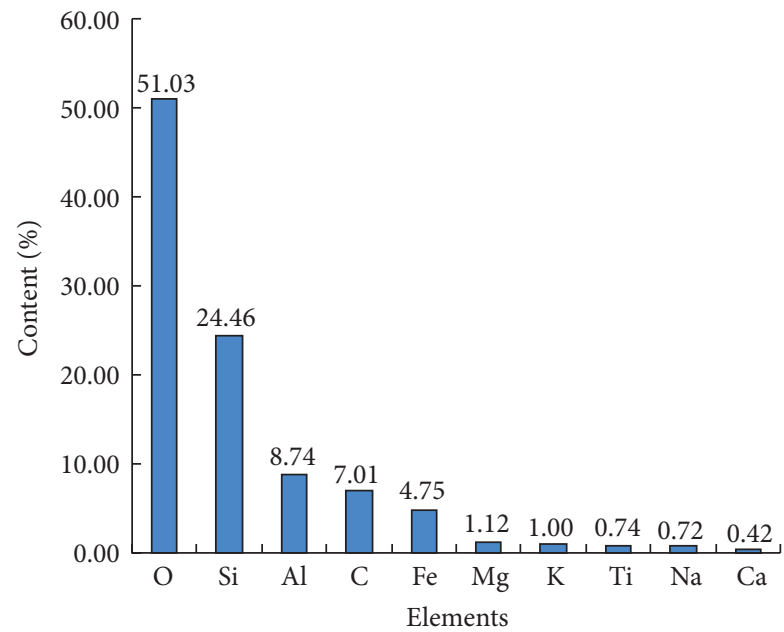

(a)

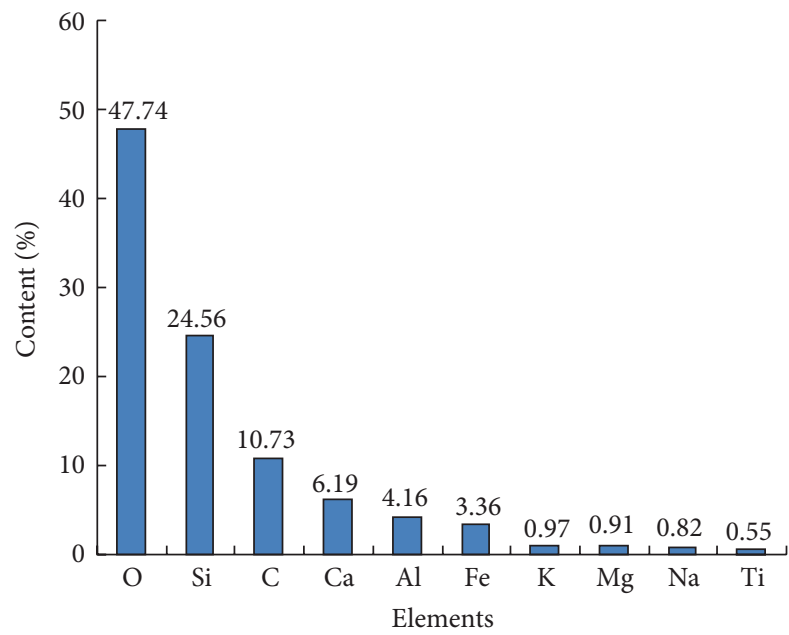

(b)

FIGURE 3: Elemental composition of the Zigong argillaceous siltstone with different weathered degrees: (a) highly weathered and (b) moderately weathered.

used different mechanical experiments and microtechniques to study the strength characteristics of the argillaceous siltstone with different moisture content and degree of weathering.

2.2. Laboratory Experiments. In general, rock strength parameters often show a decreasing trend as water content increases. The accurate estimation of rock strength parameters is of great importance in many engineering practices, especially for the stability assessment of dam foundations and soft rock roadways $[8,9,11]$. The microstructure and material composition of rock mass can reflect rock physical and mechanical properties. Therefore, it is meaningful to analyze the change of its internal structure and composition with different moisture content and degree of weathering. Here, the Zigong argillaceous siltstone was selected for sampling. These samples of the argillaceous siltstone were separated into four typical groups, which were natural highly weathered, saturated highly weathered, natural moderately weathered, and saturated moderately weathered. The moderately weathered siltstone appears mauve, and the rock mass contains some joints and cracks, resulting in its low strength. As for the highly weathered siltstone, it is deep purple with lower strength, and some parts can be crushed in hand.

Parts of rock samples with different degree of weathering were immersed into water fully for $48 \mathrm{~h}$ to ensure those samples to absorb as much water as possible which can be regarded as saturation state in the present study. As shown in Figure 4, the average density of the natural highly weathered rock samples is lower than the natural moderately weathered rock from $1.98 \mathrm{~g} / \mathrm{m}^{3}$ to $2.38 \mathrm{~g} / \mathrm{m}^{3}$, and the average density increases about $5 \%$ from natural condition to saturated condition.

Aimed to study the water-softening for mechanical properties of the Zigong argillaceous siltstones under different degree of weathering, this paper selected three types of 


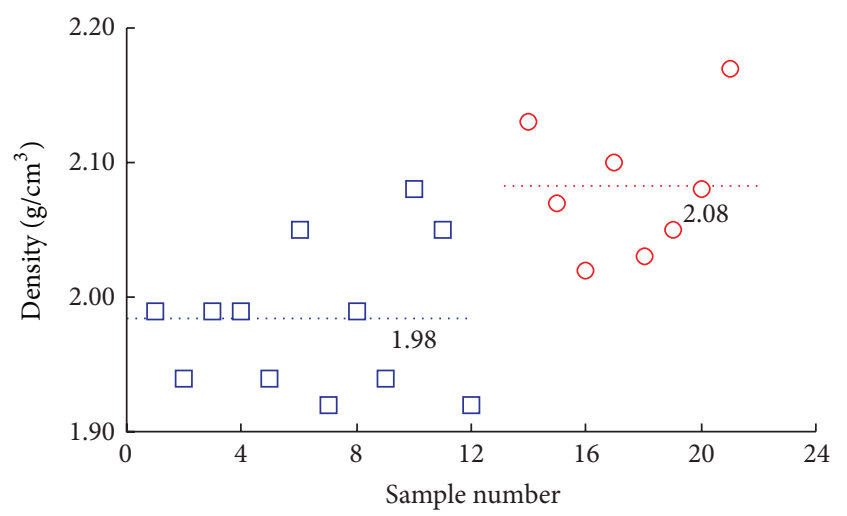

Natural

Saturated

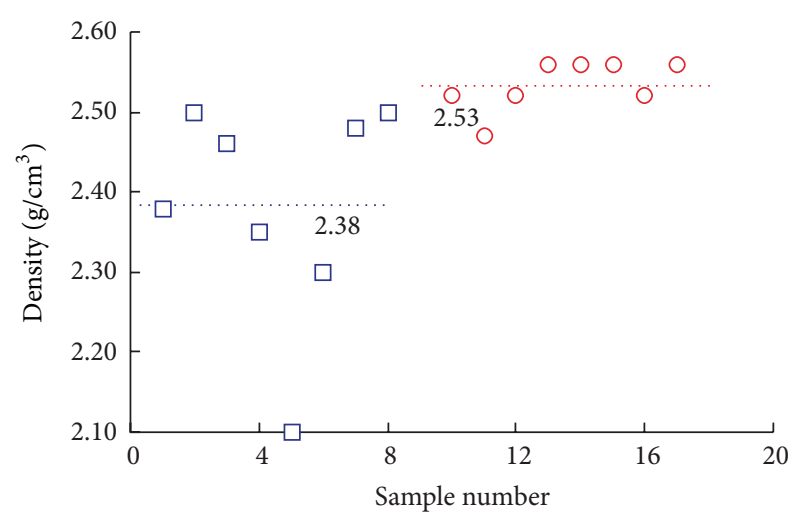

$\square$ Natural

Saturated

(a)

(b)

FIGURE 4: Test results for the density of the Zigong argillaceous siltstone under different conditions: (a) highly weathered and (b) moderately weathered.

mechanical tests: uniaxial compression test, triaxial compression test, and direct shear test. In addition, the differences of internal microstructural characteristics and material composition were also analyzed using scanning electron microscope (SEM) and energy dispersive X-ray microanalysis (EDXMA).

2.2.1. Mechanical Tests. In order to study the strength parameters of the above four typical Zigong argillaceous siltstones, two kinds of standard cylindrical samples dimensions $(50 \mathrm{~mm}$ in diameter and $100 \mathrm{~mm}$ in length and $50 \mathrm{~mm}$ in diameter and $50 \mathrm{~mm}$ in length) were cut and weighted (as shown in Figure 5(a)). These specimens were separated into two typical groups (Figure 5(b)), the samples of dimensions (50 $\mathrm{mm}$ in diameter and $100 \mathrm{~mm}$ in length) were tested to measure their uniaxial and triaxial compressive strengths using MTS 815 rock mechanics test systems, and the samples of dimensions ( $50 \mathrm{~mm}$ in diameter and $50 \mathrm{~mm}$ in length) were tested to measure shear strength using a direct shear testing machine. MTS 815 rock mechanics test systems can test many types of samples from soft sandstone to high-strength brittle rock using a three-axis stabilized pressure system and control system (Figure 5(c)). These systems combine versatile servohydraulic load frames with precise digital controls, flexible software, and specialized accessories for uniaxial and triaxial compressive tests. The direct shear testing machine includes a loading frame, a shear box, two oil pressure power supplies, a control system, a data acquisition, and display system (as shown in Figure 5(d)). The maximum normal force of the shear testing system is $500 \mathrm{kN}$, and the maximum tangential force is $300 \mathrm{kN}$. The testing time and the testing load (including the normal and tangential forces) of each specimen can be recorded directly during the testing process.

According to the requirements of international rock mechanics regulations $[8,12-14]$, rock samples of the above four typical groups were chosen to measure their uniaxial compressive strength and stress-strain curve by controlling displacement speed as $0.1 \mathrm{~mm} / \mathrm{min}$. To gain the triaxial strength of natural argillaceous siltstone, four confining pressures were applied: $0 \mathrm{MPa}, 1.0 \mathrm{MPa}, 2.0 \mathrm{MPa}$, and $3 \mathrm{MPa}$. The deviator stress $\sigma_{1}-\sigma_{3}$ was obtained from the ratio of the applied axial load after the designated hydrostatic confining pressure was reached for the cross-sectional area of these specimens. The maximum principal stress $\sigma_{1}$ can also be calculated by the summation of the deviator stress $\sigma_{1}-\sigma_{3}$ and the confining stress $\sigma_{3}$.

For direct shear test, 20 rock samples (the test sample is a cylinder with diameter $50 \mathrm{~mm}$ and height of $50 \mathrm{~mm}$ ) were performed to determine the shear strength of the Zigong argillaceous siltstones with different moisture content and degree of weathering.

2.2.2. Microstructure and Material Composition Tests. According to the surface morphology and material composition of rock samples, scanning electron microscope tests were carried out by JSM-7500 housed in the Analytical \& Testing Center Sichuan University (Chengdu), China, which can analyze material micromorphology including surface morphology, fracture morphology, and phase structure analysis. Here, the microscopic images were collected from fracture surfaces of the soft rock samples. By scanning electron microscope, the microstructural differences of rock samples were determined. Finally, combined with the results of the above three mechanical tests, rocks' surface microstructure can be used to explain the water-softening mechanism of the Zigong argillaceous siltstone.

The physical and mechanical properties of rock mass depend largely on its material composition; especially when encountering water, some minerals can be easy to react with water which can change rock microstructure and decrease rock strength. For the red-bed soft rocks of Sichuan basin, quartz, calcite, and clay minerals are the major components, and the minor ingredients are feldspar, mica, gypsum, and others, where various specific minerals are composed of a series of oxides in rocks. For example, silica $\left(\mathrm{SiO}_{2}\right)$ is present 

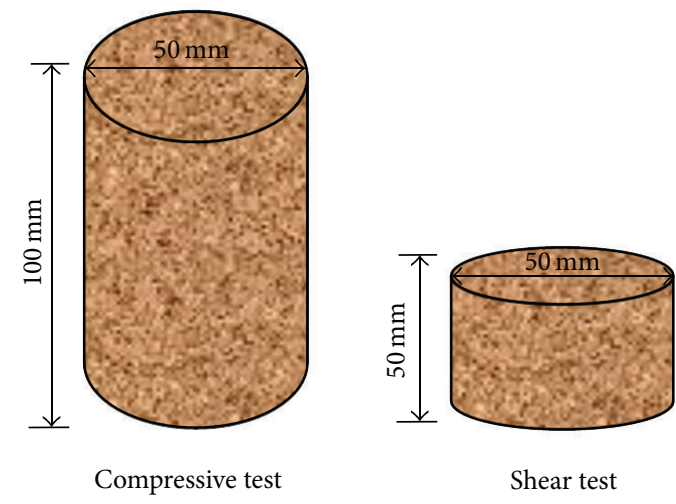

(a)

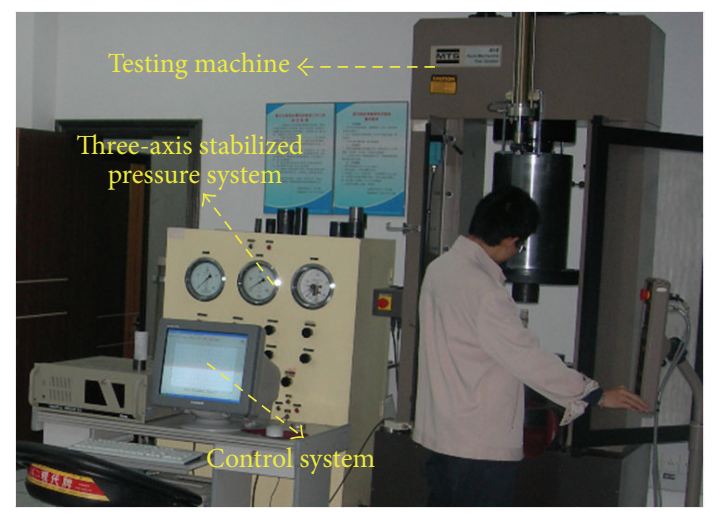

(c)

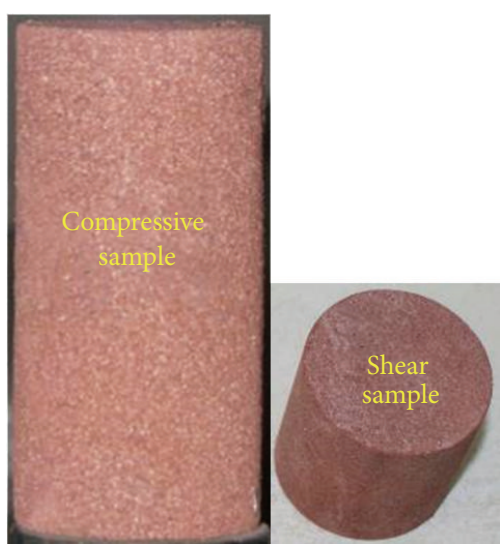

(b)

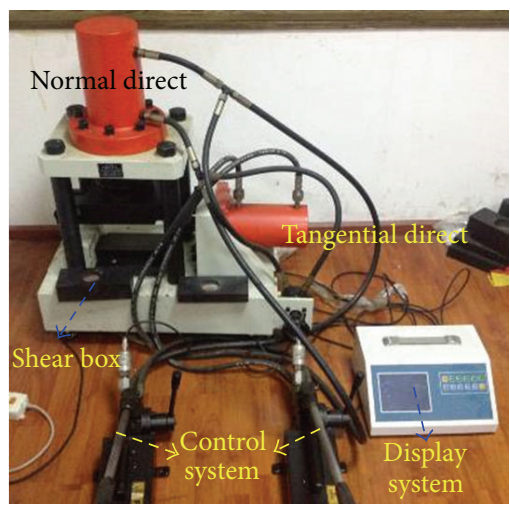

(d)

Figure 5: Laboratory test sample size and apparatus: (a) sample size used for the laboratory tests; (b) two natural rock samples for different test; (c) compressive test device (MTS 815 rock mechanics test systems); and (d) direct shear strength test device.

in the form of complex clay minerals including montmorillonite and kaolinite, primary silicates, and silica-free. Alumina $\left(\mathrm{Al}_{2} \mathrm{O}_{3}\right)$ is the basic component of complex clay minerals and primary silicates, and calcium oxide $(\mathrm{CaO})$ mainly exists in carbonates form. Besides, iron oxide $\left(\mathrm{Fe}_{2} \mathrm{O}_{3}\right)$ has great influence on the color of red-bed soft rocks. Potassium and sodium oxide $\left(\mathrm{K}_{2} \mathrm{O}\right.$ and $\left.\mathrm{Na}_{2} \mathrm{O}\right)$ are absorbed by clay minerals in the form of potassium and sodium ions, respectively, which are the components of hydromica and clay-mica. Therefore, the paper analyzed the difference of the oxides' composition for the Zigong argillaceous siltstone with different degree of weathering by scanning material surface using energy dispersive X-ray microanalysis (EDXMA).

\section{Results}

Rock strength parameters are very important for engineering design, such as rock slopes and roadways, which often decrease with the increase of moisture content and degree of weathering $[2,11,15,16]$. In general, rock strength shows a decreasing trend with the increase of water content $[10$, $13,17,18]$, mainly due to water adsorption and subsequent expansion, which can cause failure and collapse for rock mass ultimately.
3.1. Evolution of Compressive Strength. Compressive strength is the most widely used parameter in the rock engineering $[13,16]$. In general, the greater water content often means the lower compressive strength of rock mass. The above four typical specimens were tested to determine the uniaxial compressive strength based on the requirements of international rock mechanics regulations. The test results reveal clearly that water can significantly affect rock compressive strength, and the softening coefficients are 0.46 and 0.58 for the moderately and highly weathered Zigong argillaceous siltstones, respectively (Table 1). As shown in Table 1, the average uniaxial compressive strength (UCS) of moderately weathered rock $(20.46 \mathrm{MPa})$ is larger than the highly weathered rock $(6.87 \mathrm{MPa})$ under natural condition, and the corresponding softening degree is smaller.

Test results can reveal that the Zigong argillaceous siltstone is much sensitive to water. Figure 6(a) shows the stressstrain curves of the highly and moderately weathered Zigong argillaceous siltstones during uniaxial compression tests. As shown in Figure 6(a), the axial strain of the highly weathered rock is greater than the moderately weathered with the rising of the axial stress. According to the failure phenomena of rock samples (Figure 6(b)), the splitting failure occurred in rock samples of the argillaceous siltstones, and the deformation 
TABLE 1: The uniaxial compressive strength of the argillaceous siltstone samples.

\begin{tabular}{|c|c|c|c|c|c|c|}
\hline \multirow{2}{*}{ Condition } & \multicolumn{3}{|c|}{ Highly weathered } & \multicolumn{3}{|c|}{ Moderately weathered } \\
\hline & Sample & UCS (MPa) & Average (MPa) & Sample & UCS (MPa) & Average (MPa) \\
\hline \multirow{3}{*}{ Natural } & tl-N-1 & 7.19 & \multirow{3}{*}{6.87} & $\mathrm{t} 2-\mathrm{N}-1$ & 19.21 & \multirow{3}{*}{20.46} \\
\hline & $\mathrm{t} 1-\mathrm{N}-2$ & 6.52 & & $\mathrm{t} 2-\mathrm{N}-2$ & 21.53 & \\
\hline & $\mathrm{t} 1-\mathrm{N}-3$ & 6.91 & & $\mathrm{t} 2-\mathrm{N}-3$ & 20.65 & \\
\hline \multirow{3}{*}{ Saturated } & t1-S-1 & 2.63 & \multirow{3}{*}{3.13} & $\mathrm{t} 2-\mathrm{S}-1$ & 10.89 & \multirow{3}{*}{11.86} \\
\hline & tl-S-2 & 2.23 & & $\mathrm{t} 2-\mathrm{S}-2$ & 13.43 & \\
\hline & t1-S-3 & 4.53 & & $\mathrm{t} 2-\mathrm{S}-3$ & 11.26 & \\
\hline
\end{tabular}

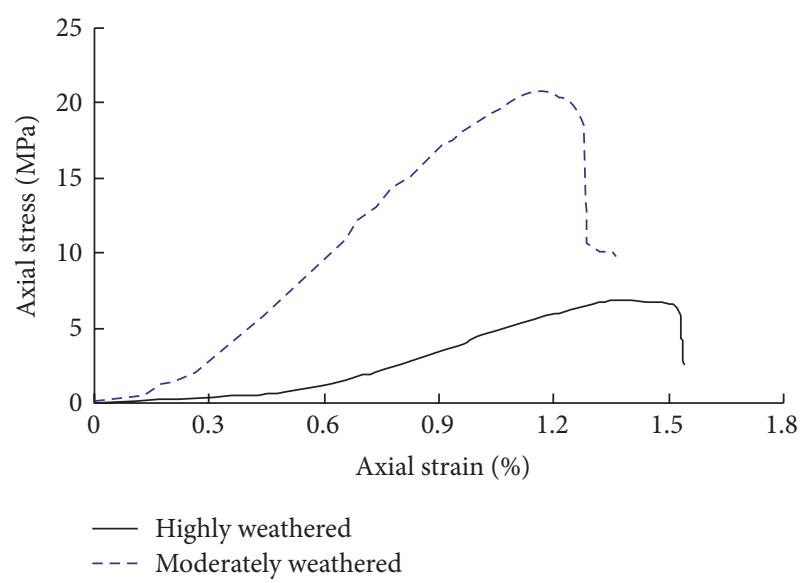

(a)

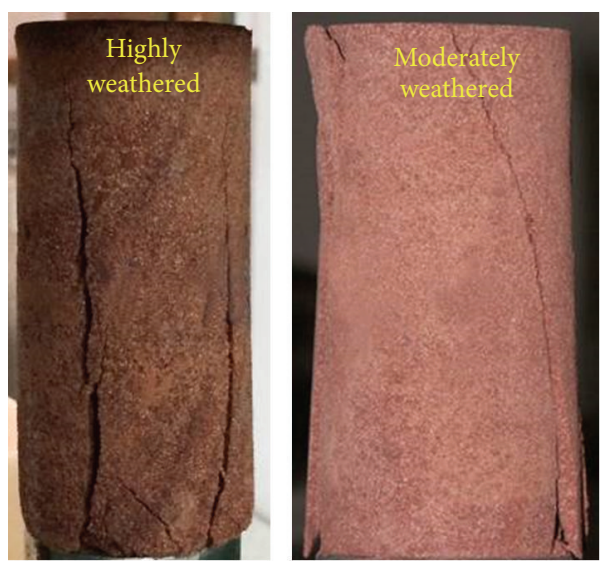

(b)

FIGURE 6: The results of the uniaxial compressive tests: (a) stress-strain curves and (b) the failure types of the Zigong argillaceous siltstone with different degree of weathering.

is more obvious with the increasing degree of weathering (Figure 6(a)).

The highly and moderately weathered rocks showed some characteristics of plastic and soft rock deformation. With the increase of axial stress, axial strain of the two group rocks increased gradually. Comparing the two deformation curves (as shown in Figure 6(a)), the average elastic modulus of the highly weathered rock sample is far lower than the moderately weathered rock sample, which proves that the degree of weathering has great influence on their deformation properties. By comparing the compressive strength and deformation characteristics, the moisture content and degree of weathering also have great effect on the Zigong argillaceous siltstones; that is to say, the increase with moisture content and degree of weathering of the argillaceous siltstone leads to its compressive strength reduction.

3.2. Shear Strength Parameters. MTS 815 rock mechanics test systems are available to support triaxial testing, including compression, creep, extension, and deformational stress pathways. The paper only chose one group totally 4 cylindrical samples of dimensions $50 \mathrm{~mm} \times 50 \mathrm{~mm}$ of the natural highly weathered argillaceous siltstone. For the triaxial compressive test, four confining pressures were applied, and the confining pressure $\sigma_{3}$ was $0 \mathrm{MPa}, 1.0 \mathrm{MPa}, 2.0 \mathrm{MPa}$, and 3.0 $\mathrm{MPa}$. In the present study, the deviator stress $\sigma_{1}-\sigma_{3}$ can be obtained from the ratio of the applied axial load after the designated hydrostatic confining pressure is reached to the cross-sectional area. The peak compressive strength $\sigma_{1}$ can be obtained by the summation of the deviator stress $\sigma_{1}-\sigma_{3}$ and the confining pressure $\sigma_{3}$. According to Mohr-Coulomb criterion [19], the cohesion (c) and the internal friction angle $(\varphi)$ can be calculated based on the geometric relationship of the confining pressure $\sigma_{3}$ and the peak compressive strength $\sigma_{1}$ (Figure $\left.7(\mathrm{a})\right)$. The test results are that the cohesion is equal to $1.604 \mathrm{MPa}$ and the internal friction angle is $38.06^{\circ}$, and rock samples showed typical shear failure characteristics as shown in Figure 7(b).

For the direct shear test, the above four typical specimens were tested using five different normal pressures. The axial forces were $0.2 \mathrm{kN}, 0.5 \mathrm{kN}, 0.8 \mathrm{kN}, 1.1 \mathrm{kN}$, and $1.5 \mathrm{kN}$ for the saturated highly weathered argillaceous siltstone because its strength is very low; for the other three groups, the axial forces were $0.5 \mathrm{kN}, 1.0 \mathrm{kN}, 1.5 \mathrm{kN}$, and $2.0 \mathrm{kN}$, respectively. The relationship between normal stresses and shear stresses can be drawn in a figure and used to determine the shear strength parameters of rock. Figure 8 shows the direct shear test results of the Zigong argillaceous siltstone under different conditions.

The criteria values of rock physics index can be considered same as the rock mass, but rock shear strength parameters must be reduced as shear strength of rock mass 


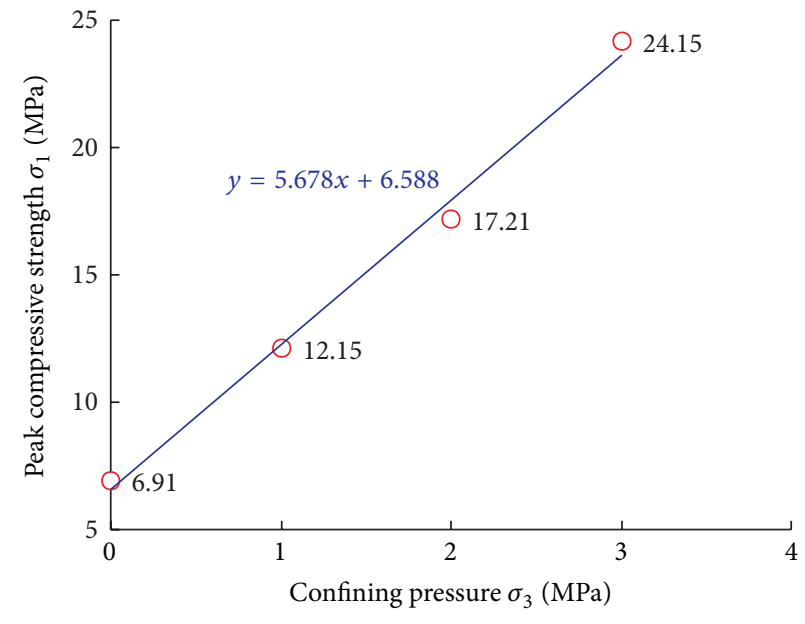

(a)

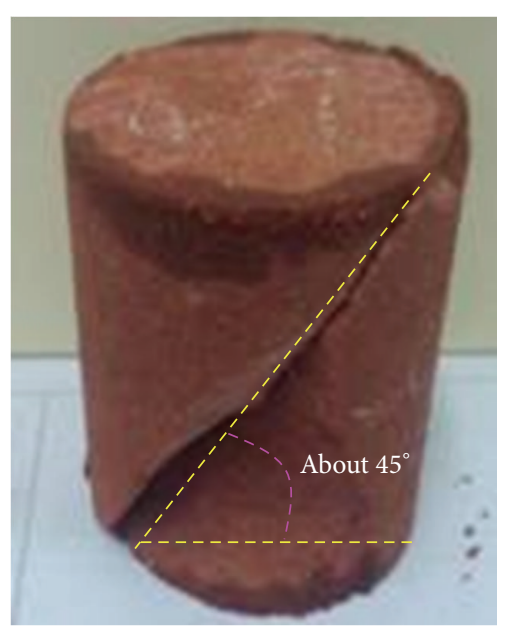

(b)

FIGURE 7: The results of the triaxial compressive test: (a) relationship between the confining stress and the failure stress of rock sample and (b) the failure pattern of the natural highly weathered Zigong argillaceous siltstone.

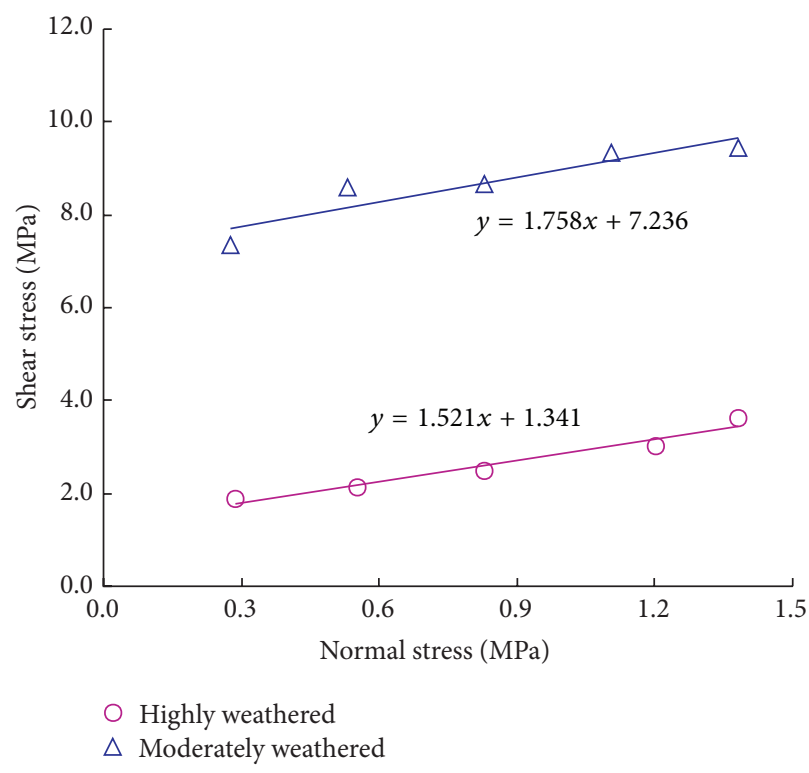

(a)

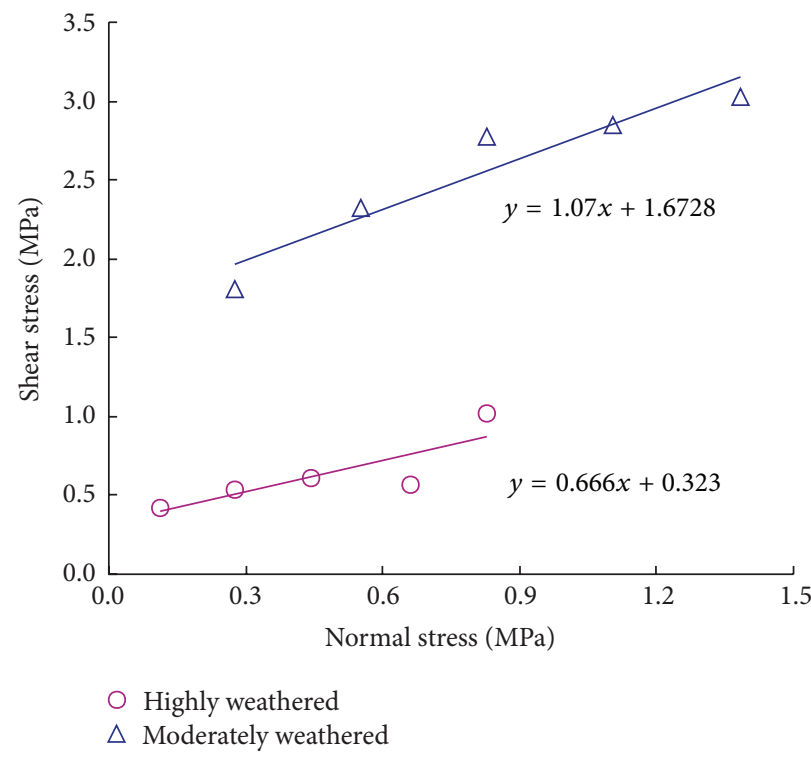

(b)

FIGURE 8: The results of the direct shear tests: (a) natural rock samples and (b) saturated rock samples.

$[12,20,21]$ : reducing the rock internal friction angle to $80-$ 95 percent based on the rock mass integrity and reducing the rock cohesion to 20-30 percent. According to Figure 8 and the above principles, the shear strength parameters were calculated including the cohesion $(c)$ and the internal friction angle $(\varphi)$ (Table 2).

For the natural Zigong argillaceous siltstone, the cohesion of the highly weathered rock was significantly lower than the moderately weathered rock decreasing from 1.447 MPa to $0.335 \mathrm{MPa}$ and the internal friction angle lower by about $22 \%$ from $48.30^{\circ}$ to $37.55^{\circ}$. After contacting with water, the shear strength reduces significantly such that the cohesion decreases about $80 \%$ for the highly and moderately weathered rocks. As shown in Table 2, the cohesion of the red-bed soft rock is more sensitive encountering water than the internal friction angle. Above all, the shear strength reduces significantly which proves water can soften the red-bed soft rock obviously. According to the test results, the shear strength of the Zigong argillaceous siltstone is also sensitive to water, perhaps because water can decrease frictional shearing resistance or change the characteristics of clay mineral constituents of the red-bed soft rock. 
TABLE 2: Shear strength parameters of the silty mudstones under different condition.

\begin{tabular}{lcccc}
\hline \multirow{2}{*}{ Samples } & \multicolumn{2}{c}{ Natural condition } & \multicolumn{2}{c}{ Saturated condition } \\
& $c(\mathrm{MPa})$ & $\varphi\left({ }^{\circ}\right)$ & $c(\mathrm{MPa})$ & $\varphi\left({ }^{\circ}\right)$ \\
\hline Highly weathered & 0.335 & 37.55 & 0.065 & 26.94 \\
Moderately weathered & 1.447 & 48.30 & 0.268 & 45.34 \\
\hline
\end{tabular}

\section{Discussions}

Water-rock interaction is one of the frontier topics in geotechnical engineering. Under certain seepage pressure and hydrodynamic condition, rock can produce the physicochemical action and mechanical process, which are the basic reasons of engineering rock deformation and failure occurring $[5,10-16$, $18,22,23]$. Especially for some soft rocks, where intact, they have good mechanical properties under natural conditions, and yet, there will be the rapid expansion, disintegration, and softening in water saturation, which results in significant reductions of the mechanical properties of the rock.

4.1. Effect of Water on the Mechanical Properties of Soft Rock. Soft rocks can produce various changes of physical, chemical, and mechanical properties when encountering water, which is among the most important factors affecting rock strength, and rock strength reduction has been the chief technique problem controlling the stability of surrounding rock in underground engineering. In the field of mining, coal mine tunnel traverses mostly soft rocks' strata and its water stability is poor. Under high temperature, high stress, and high pressure conditions, the softening property of soft rocks is more obvious [7]. And, water-induced strength softening effect has been analyzed based on correlation between water content and rock mechanical properties including UCS and modulus of elasticity [14, 18, 24, 25].

The test results in our studies reveal that the cohesion and internal friction angle of the natural Zigong argillaceous siltstone are larger than those of the corresponding saturated rocks (Table 2). Therefore, the presence of water in rock samples can be concluded to weaken the shear strengths of the red-bed soft rock. And its deformation decreases from highly weathered to moderately weathered. Water often plays a key parameter in the water-weakening to cause the reduction of rock strength $[10,16,22]$. Risnes et al. (2003) studied the water-weakening effect on chalk. They performed compressive tests and Brazilian tests revealing that the variations in mechanical strength are correlated with the activity of water in the brines. They observed a linear trend between reduction of water activity and the corresponding increase in strength [26]. In addition, Zhou et al. (2005) ran a series of tests to obtain the mechanical property of silt mudstones in different saturation times ( 1 month, 3 months, 6 months, and 12 months) and drew a conclusion that the uniaxial compressive strength, cleave tensile strength, and shear strength conformed to an exponent curve after different saturated time on which the point in 6 months was the critical time for mechanical properties changing from gradually declining to stable state [10].
According to the results of the above mechanical tests, water and degree of weathering both have great effect on the mechanical properties of the red-bed soft rock. Aiming at rocks with different degree of weathering and saturation condition, rocks often exhibit a big difference in mechanical characteristics. In general, rock strength is larger with a lower weathering degree and moisture contents. Of course, some researchers have also studied the effect of water on rock strength and internal structure. First, the presence of water can reduce uniaxial compressive strength (UCS) in many sedimentary rocks and even some metamorphic rocks experimentally $[13,16]$. Water can influence significantly the compressive strength and deformability of rocks, even though the water contents of rocks are not high for the natural and saturated rocks. And the reduction of strength by water content is found to be related to a reduction of friction angle and cohesion in the Mohr-Coulomb failure criterion. Li et al. (2012) thought the critical factors influencing rock strength and stiffness include material factors, such as constituent mineral composition, porosity, anisotropy, and discontinuity, and environment factors such as water content, temperature, and confining pressure [12]. Besides, it is quite difficult to evaluate and correlate these influencing factors by using only one index. So the paper also analyzed the microstructure and material composition for the above tested rock samples to study the water-softening mechanism and the influence of weathering degree.

4.2. Water-Softening Mechanism. The Zigong argillaceous siltstone is a sedimentary rock and is mainly composed of silt particles. With the help of scanning electron technique, the microstructures of fracture surfaces were determined for the above four typical rock samples (Figure 9). According to the microstructures' results, the natural red-bed soft rocks with different degree of weathering present a slab structure, and the phenomenon of the moderately weathered is more obvious that the fracture surface of the fragment is blocky with regular edges (Figures 9(a) and 9(c)). As shown in Figures 9(b) and 9(d), the Zigong argillaceous siltstone shows good water permeability performance and the rock shows granular structure at a magnification of $\times 70$ and $\times 100$.

The differences of microstructure are obvious for the above typical rock samples with different conditions. According to mechanical tests, the shear strength of the triaxial test is bigger than the direct shear test. The possible reason was that the existing of the confining pressure $\left(\sigma_{3}\right)$ improves the loose structure of the highly weathered argillaceous siltstone as observed in Figure 9(a). When encountering water to saturation condition, there are big differences between natural and saturated rocks. For example, the fracture surfaces of the natural argillaceous siltstone are smoother and the shape of the fragment is more irregular than the saturated rock. Combined with the microstructure imageries, the phenomenon of water swell occurred in the saturated rocks. Figure 9 can help explain the cause of the change in the strength parameter that there are remarkable differences with its different water content and degree of weathering for the argillaceous siltstones. For the saturated rock, the fracture surfaces show the irregular scatter of silt particle because 


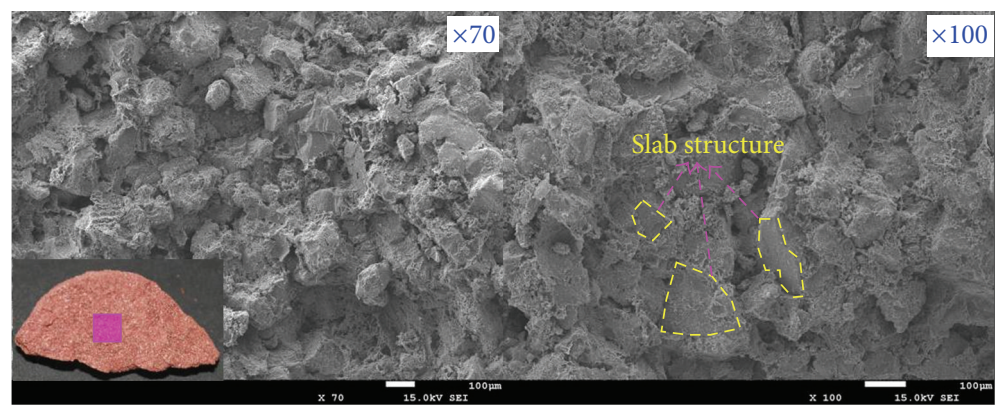

(a)

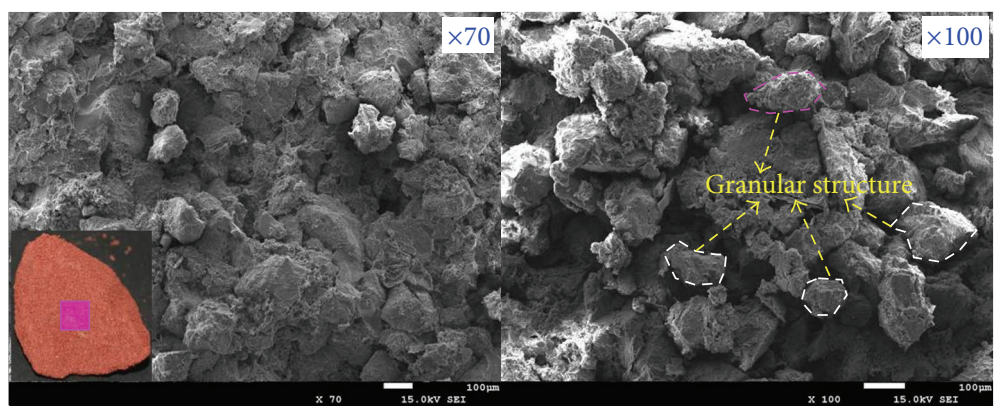

(b)

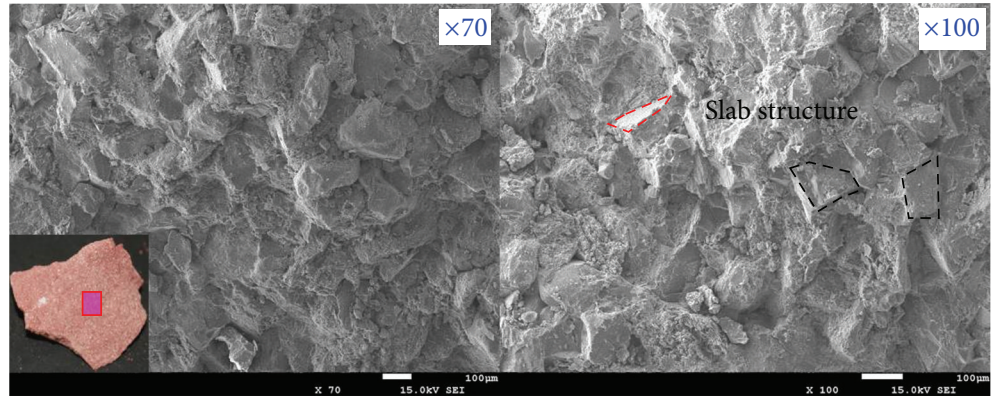

(c)

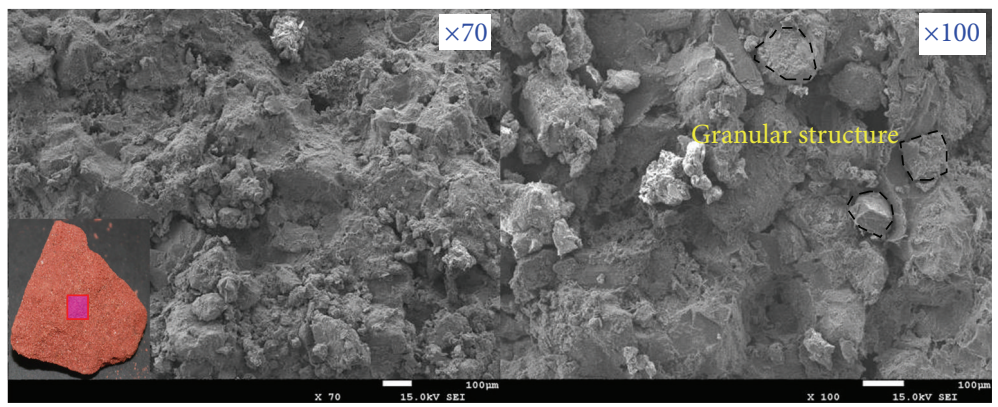

(d)

FIGURE 9: Microstructural characteristics of the Zigong argillaceous siltstone with different degree of weathering (SEM images): (a) natural highly weathered; (b) saturated highly weathered; (c) natural moderately weathered; and (d) saturated moderately weathered.

these soluble materials dissolve in the water leading to loosening of the structure. For the triaxial compressive test, the original loose structure became compact structure with the aid of the confining pressure $\sigma_{3}$ (Figure 9(a)); therefore, the shear strength parameters are bigger than the direct shear test for the highly weathered argillaceous siltstone. Combined with Figure 9, the monolithic turned into pieces and the fracture surface produced some microscopic pores for the saturated rocks. Changes in microstructure eventually lead to reduced density, development of the pore system, and increased degree of argillation. As reported in literature [2, 11, 20, 27$30]$, it can be inferred that the changes in microstructure may be an important reason for rock softening and deterioration. 


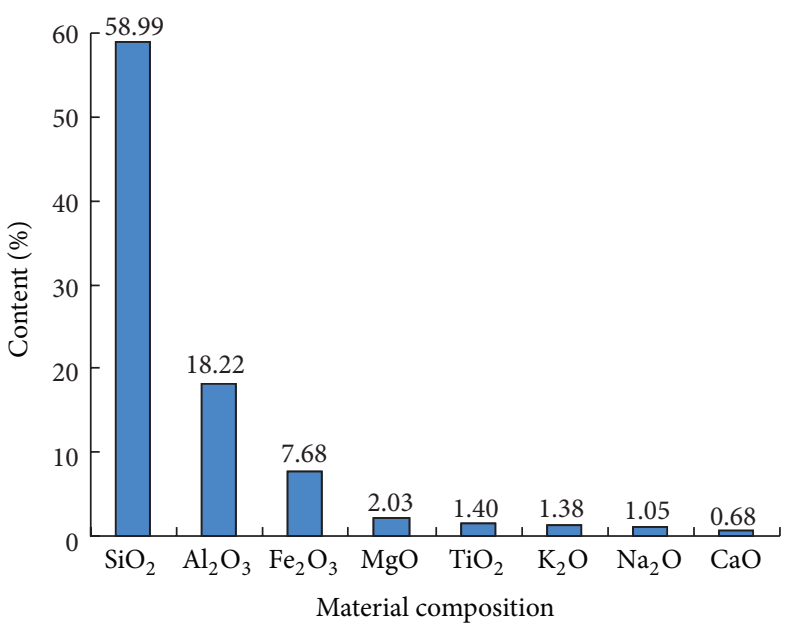

(a)

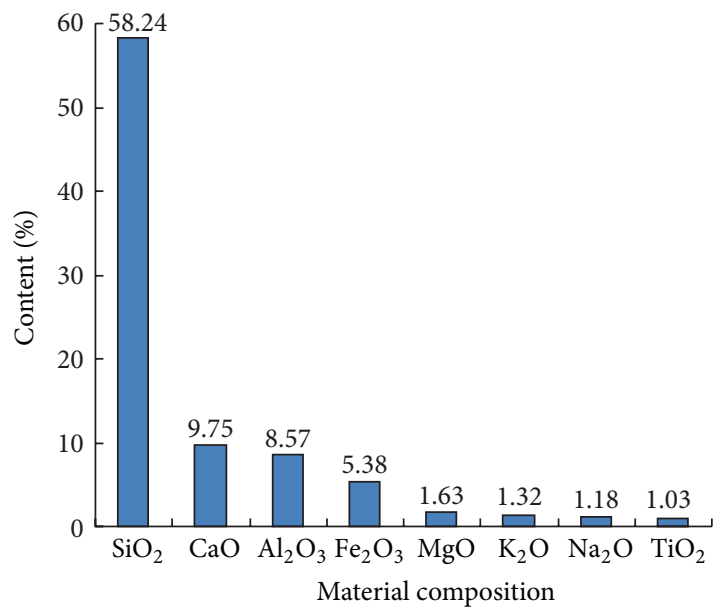

(b)

FIGURE 10: Material compositions of the natural Zigong argillaceous siltstone with different degree of weathering: (a) highly weathered and (b) moderately weathered.

From the above analysis, the argillaceous siltstone is sensitive to water, likely because the rock contains some clay minerals and soluble materials. According to Figure 10, the content of silica $\left(\mathrm{SiO}_{2}\right)$ is the highest in all oxides, accounting for about $60 \%$, which indicates that the argillaceous siltstone contains many complex clay minerals, primary silicate minerals, and free silica. Besides, for the moderately weathered argillaceous siltstone, calcium oxide $(\mathrm{CaO})$ and alumina $\left(\mathrm{Al}_{2} \mathrm{O}_{3}\right)$ account for about $10 \%$ and $9 \%$, respectively, (as shown in Figure 10(b)), which prove that there are a lot of carbonates and complex clay minerals in the red-bed soft rock. Comparing with Figure 6(b), its content of calcium oxide $(\mathrm{CaO})$ and alumina $\left(\mathrm{Al}_{2} \mathrm{O}_{3}\right)$ is very different from Figure 6(a), which indicates the content of clay minerals is higher, and the carbonate content is obviously decreased in the highly weathered argillaceous siltstone. The increase of clay minerals makes it more sensitive to water than the moderately weathered argillaceous siltstone.

With the aid of pore water pressure, the water can change the characteristics of clay mineral constituents of the red-bed soft rock. When encountering water, these soluble materials of rock samples can easily dissolve in the water which will cause the microstructural change and the reduction of strength parameters. Therefore, some internal materials dissolved in the water which may be the reason why the slab structure becomes granular structure for the microstructure images.

Many researchers thought the existing pores and clay minerals in the microstructure are the strength weakening reasons of soft rock affected by water $[10,11,16]$. The mechanical tests' results show that the shear strength parameters of saturated rocks mass reduced significantly, mainly because water can decrease frictional shearing resistance or change the characteristics of clay mineral constituents of the redbed soft rock. Therefore, it is necessary to study the physicalchemical softening effect on microstructure and material composition in the future. By analyzing the microscopic mechanism of water-rock interaction, the difference of rock internal microstructure is the main reason for influencing the water-softening properties, and the soluble oxides such as $\mathrm{CaO}, \mathrm{K}_{2} \mathrm{O}$, and $\mathrm{Na}_{2} \mathrm{O}$, are another reason. The Zigong argillaceous siltstones underwent significant changes in microscopic morphology after saturation condition. Due to mineral leaching induced by physicochemical reactions including water flow, water leaching, and other water chemistry reactions, microstructural changes of the Zigong argillaceous siltstone are the main reason of water-softening.

Similar results of water-weakening effect have also been reported by some researchers [13-16, 21, 25, 26] on different kinds of rock such as clay-bearing rock, granite, chalk, shale, sandstone, and gypsum. Some studies have revealed that the loss of strength is most pronounced in clay-rich rock due to softening and expansive effect of hydrated clay $[5,10,15]$. Despite the fact that the harmful effects of water on different types of rock have been investigated extensively, the corresponding fundamental mechanism of water-induced strength reduction and deformability is still not very clear [14]. Compared with all test results of the natural and saturated argillaceous siltstones, the results of the work indicate that the increase of moisture content of the Zigong argillaceous siltstone leads to water interacting with mineral surfaces and altering the microstructure properties, which is the two main reasons for strength reduction.

\section{Conclusions}

The mechanical tests have been successfully conducted on thirty-six argillaceous siltstone rock samples, in which twenty of them were highly weathered, while sixteen of them were moderately weathered, both including natural and saturation conditions. The UCS of highly weathered rocks were about 6.87 $\mathrm{MPa}$ and $3.13 \mathrm{MPa}$, while that of moderately weathered were about $20.46 \mathrm{MPa}$ and $11.86 \mathrm{MPa}$ for the above two conditions. The shear strength of four typical rocks has also 
been obtained. From the present study, the direct shear strength generally reduced with increasing water content and degree of weathering; meanwhile, the deformation of the redbed soft rock has correlation with the weathered degree.

Present experimental studies have proved that water can influence the uniaxial compressive strength and shear strength of the red-bed soft rock, particularly for highly weathered argillaceous siltstone. The experimental results reveal the mechanical properties are correlated with the physical properties of tested rocks. Water can change not only rock microscopic structure morphology but also its internal material composition. When contacting with water, water will interact with mineral surfaces and alter their surface properties; therefore, the existing soluble materials are the reason for the difference of microstructure characteristics. By observing the surface morphology and pores, the change of microstructure can cause rock instability along weakness planes and decrease rock strength parameters. And high moisture content can also decrease durability and hardness of rock specimens.

Experimental results show that the microstructure characteristics can reflect rock strength well. In addition, the water-softening effect is obvious especially for the redbed soft rock with higher degree of weathering, so special attention should be paid to the practical engineering when encountering groundwater or rainfall. The most important conclusion that can be drawn from this study is that the changes of the microstructure and material composition seem to be the key parameters in the water-softening mechanism. Therefore, the changes of microstructure and material composition are the main reason for the reduction of rock strength parameters.

\section{Competing Interests}

The authors declare that there is no conflict of interests regarding the publication of this paper.

\section{Acknowledgments}

This work is supported by the National Natural Science Foundation of China (51209156).

\section{References}

[1] Y. C. Guo, Q. Xie, and J. Q. Wen, "Red beds distribution and engineering geological problem in China," Chinese Journal of Hydrogeology and Engineering Geology, vol. 6, pp. 67-71, 2007 (Chinese).

[2] J. Chen, F. C. Dai, L. Xu et al., "Properties and microstructure of a natural slip zone in loose deposits of red beds, southwestern China," Engineering Geology, vol. 183, pp. 53-64, 2014.

[3] L. T. Jiang, G. N. Chen, R. Grapes, and Z. L. Peng, "Thermal origin of continental red beds in SE China: an experiment study," Journal of Asian Earth Sciences, vol. 101, pp. 14-19, 2015.

[4] G. X. Wu, B. Zhang, Y. X. Yang, and Q. Cheng, "Geology characteristics of red-layer soft rock in western region and its influence to the roadbase construction stability," Journal of
Chongqing Jiaotong University, vol. 23, no. 6, pp. 53-58, 2004 (Chinese).

[5] N. Zhang, L. B. Liu, D. W. Hou, M. C. He, and Y. L. Liu, "Geomechanical and water vapor absorption characteristics of clay-bearing soft rocks at great depth," International Journal of Mining Science and Technology, vol. 24, no. 6, pp. 811-818, 2014.

[6] M. Arnould, "Discontinuity networks in mudstones: a geological approach," Bulletin of Engineering Geology and the Environment, vol. 65, no. 4, pp. 413-422, 2006.

[7] H. Y. Guo, X. Y. Lei, Y. M. Zhang, G. X. Yang, and Z. $\mathrm{Niu}$, "Experimental research on hydrophilic characteristics of natural soft rock at high stress state," International Journal of Mining Science and Technology, vol. 25, no. 3, pp. 489-495, 2015.

[8] M. C. He, "Latest progress of soft rock mechanics and engineering in China," Journal of Rock Mechanics and Geotechnical Engineering, vol. 6, no. 3, pp. 165-179, 2014.

[9] G. C. Li, Z. H. Jiang, C. X. Lv, C. Huang, G. Chen, and M. Y. Li, "Instability mechanism and control technology of soft rock roadway affected by mining and high confined water," International Journal of Mining Science and Technology, vol. 25, no. 4, pp. 573-580, 2015.

[10] C.-Y. Zhou, Y.-M. Deng, X.-S. Tan, Z.-Q. Liu, W. Shang, and S. Zhan, "Experimental research on the softening of mechanical properties of saturated soft rocks and application," Chinese Journal of Rock Mechanics and Engineering, vol. 24, no. 1, pp. 33-38, 2005 (Chinese).

[11] X.-T. Feng, S. Li, and S. Chen, "Effect of water chemical corrosion on strength and cracking characteristics of rocks-a review," Key Engineering Materials, vol. 261-263, no. II, pp. 13551360, 2004.

[12] D. Y. Li, L. N. Y. Wong, G. Liu, and X. P. Zhang, "Influence of water content and anisotropy on the strength and deformability of low porosity meta-sedimentary rocks under triaxial compression," Engineering Geology, vol. 126, pp. 46-66, 2012.

[13] T. AL-Bazali, "The impact of water content and ionic diffusion on the uniaxial compressive strength of shale," Egyptian Journal of Petroleum, vol. 22, no. 2, pp. 249-260, 2013.

[14] I. Yilmaz, "Influence of water content on the strength and deformability of gypsum," International Journal of Rock Mechanics and Mining Sciences, vol. 47, no. 2, pp. 342-347, 2010.

[15] Z. A. Erguler and R. Ulusay, "Water-induced variations in mechanical properties of clay-bearing rocks," International Journal of Rock Mechanics and Mining Sciences, vol. 46, no. 2, pp. 355-370, 2009.

[16] X.-T. Feng, S. Chen, and S. Li, "Effects of water chemistry on microcracking and compressive strength of granite," International Journal of Rock Mechanics and Mining Sciences, vol. 38, no. 4, pp. 557-568, 2001.

[17] S. Q. Yang, H. W. Jing, Y. S. Li, and L. J. Han, "Experimental investigation on mechanical behavior of coarse marble under six different loading paths," Experimental Mechanics, vol. 51, no. 3, pp. 315-334, 2011.

[18] N. Zhang, M. C. He, and P. Y. Liu, "Water vapor sorption and its mechanical effect on clay-bearing conglomerate selected from China," Engineering Geology, vol. 141-142, pp. 1-8, 2012.

[19] N. Barton, "Shear strength criteria for rock, rock joints, rockfill and rock masses: problems and some solutions," Journal of Rock Mechanics and Geotechnical Engineering, vol. 5, no. 4, pp. 249261, 2013

[20] X.-T. Feng, S. Chen, and H. Zhou, "Real-time computerized tomography (CT) experiments on sandstone damage evolution 
during triaxial compression with chemical corrosion," International Journal of Rock Mechanics and Mining Sciences, vol. 41, no. 2, pp. 181-192, 2004.

[21] P. L. P. Wasantha, W. J. Darlington, and P. G. Ranjith, "Characterization of mechanical behaviour of saturated sandstone using a newly developed triaxial apparatus," Experimental Mechanics, vol. 53, no. 5, pp. 871-882, 2013.

[22] Y. Mikami, M. Kurashige, and K. Imai, "Mechanical response of a water-saturated core sample under opposite diametrical loadings," Acta Mechanica, vol. 158, no. 1-2, pp. 15-32, 2002.

[23] B. J. Thomson, J. A. Hurowitz, L. L. Baker et al., "The effects of weathering on the strength and chemistry of Columbia River Basalts and their implications for Mars Exploration Rover Rock Abrasion Tool (RAT) results," Earth and Planetary Science Letters, vol. 400, pp. 130-144, 2014.

[24] E. Rybacki, A. Reinicke, T. Meier, M. Makasi, and G. Dresen, "What controls the mechanical properties of shale rocks?-part I: strength and Young's modulus," Journal of Petroleum Science and Engineering, vol. 135, pp. 702-722, 2015.

[25] S. Taibi, A. Duperret, and J.-M. Fleureau, "The effect of suction on the hydro-mechanical behaviour of chalk rocks," Engineering Geology, vol. 106, no. 1-2, pp. 40-50, 2009.

[26] R. Risnes, H. Haghighi, R. I. Korsnes, and O. Natvik, "Chalkfluid interactions with glycol and brines," Tectonophysics, vol. 370, no. 1-4, pp. 213-226, 2003.

[27] E. Ishii, "Microstructure and origin of faults in siliceous mudstone at the Horonobe Underground Research Laboratory site, Japan," Journal of Structural Geology, vol. 34, pp. 20-29, 2012.

[28] N. P. Kruyt and L. Rothenburg, "On micromechanical characteristics of the critical state of two-dimensional granular materials," Acta Mechanica, vol. 225, no. 8, pp. 2301-2318, 2014.

[29] X. R. Liu, Z. J. Wang, Y. Fu, W. Yuan, and L. L. Miao, "Macro/ microtesting and damage and degradation of sandstones under dry-wet cycles," Advances in Materials Science and Engineering, vol. 2016, Article ID 7013032, 16 pages, 2016.

[30] S. M. Brooks, T. Spencer, and S. Boreham, "Deriving mechanisms and thresholds for cliff retreat in soft-rock cliffs under changing climates: rapidly retreating cliffs of the Suffolk coast, UK," Geomorphology, vol. 153-154, pp. 48-60, 2012. 

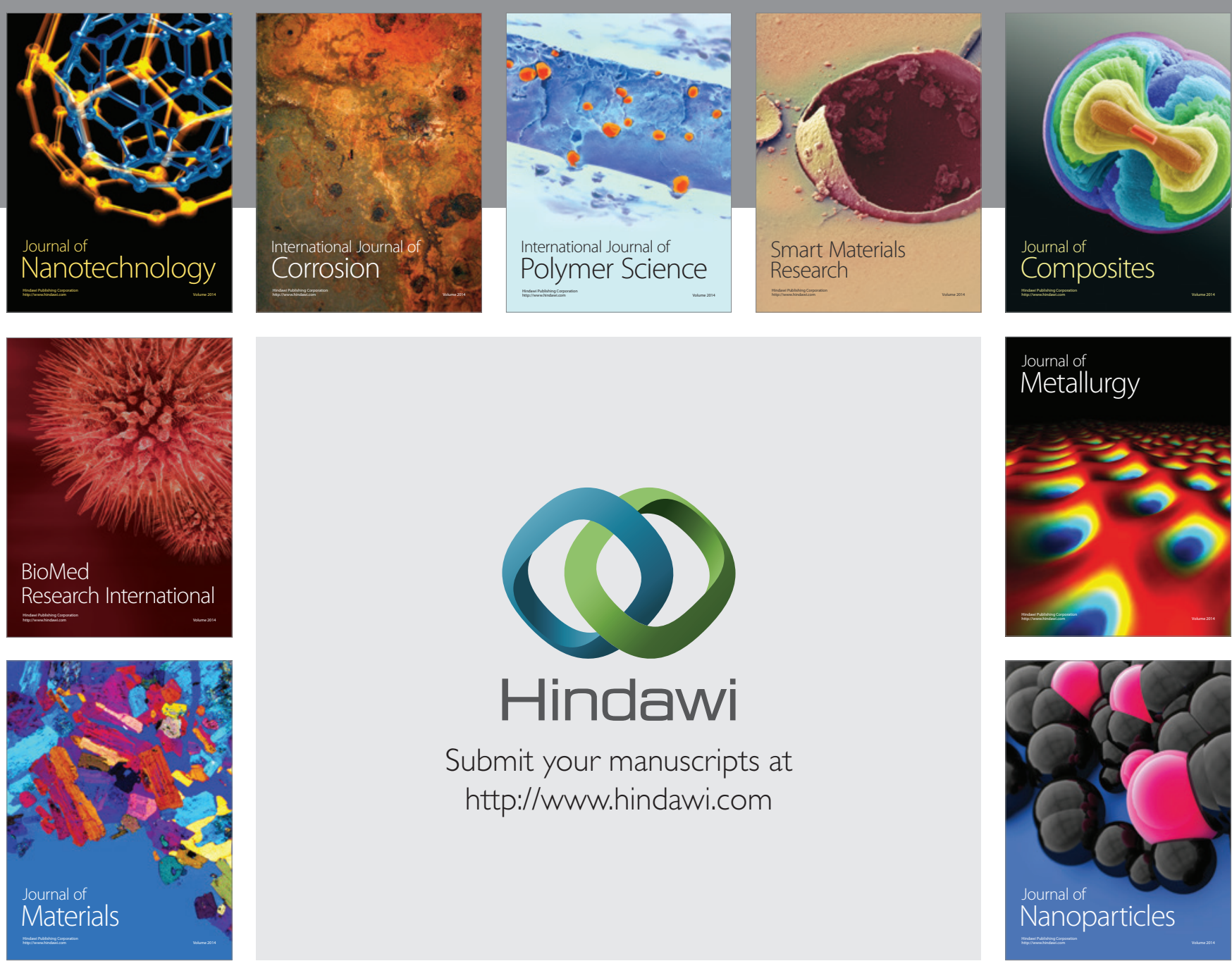

\section{Hindawi}

Submit your manuscripts at

http://www.hindawi.com

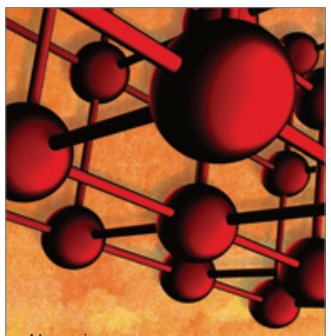

Materials Science and Engineering
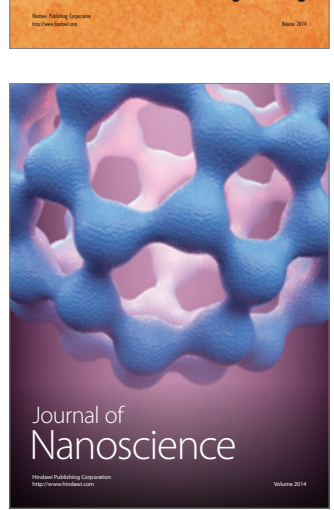
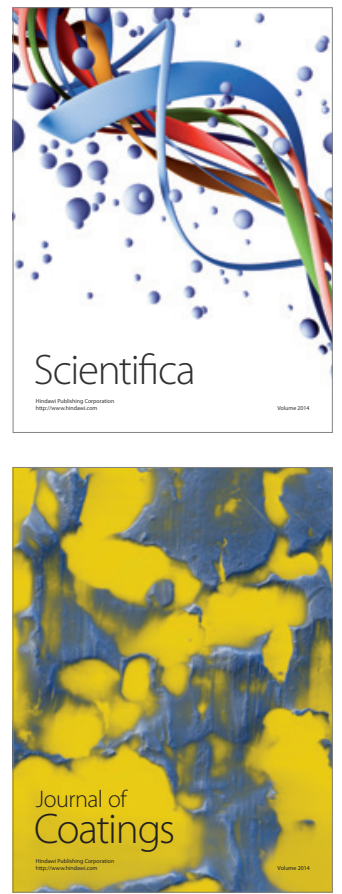
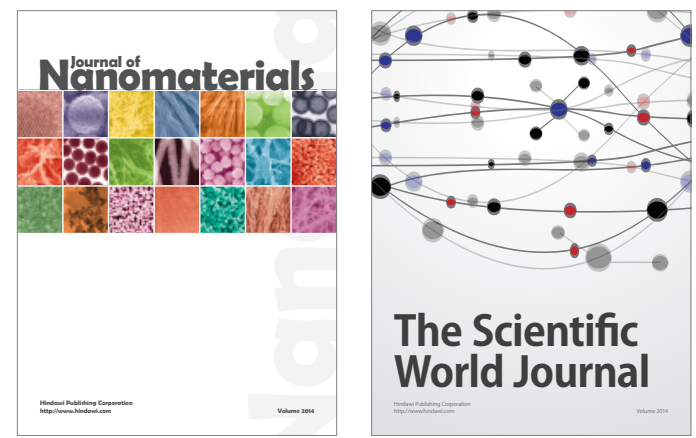

The Scientific World Journal
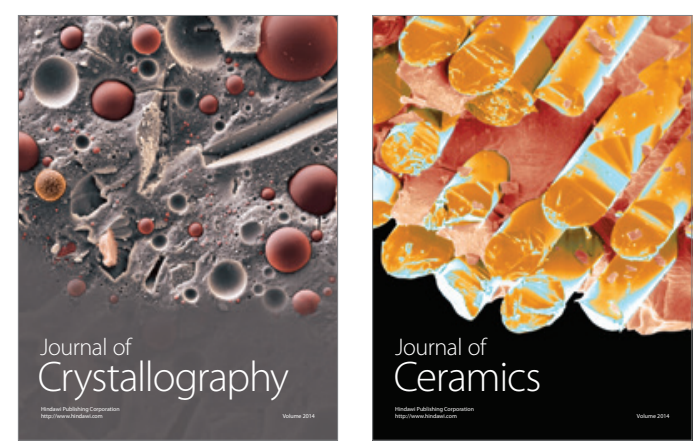
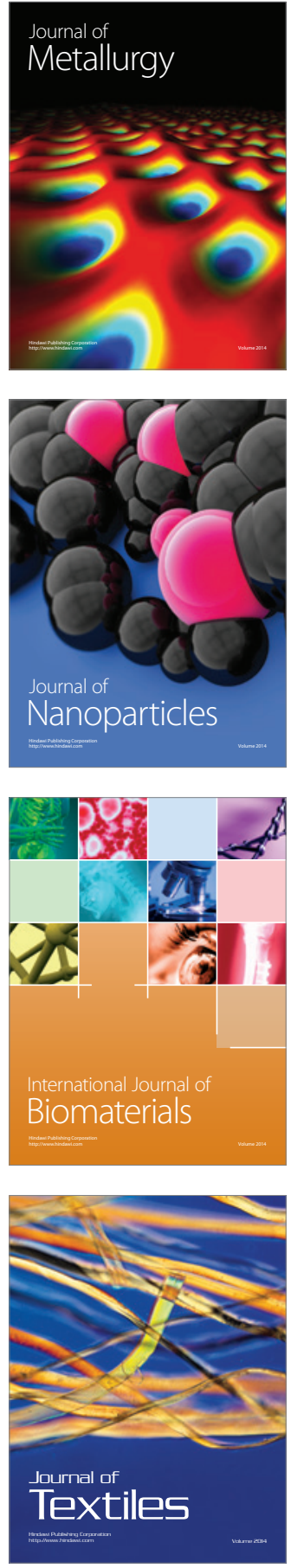